\title{
Supply chain management: implementation issues and research opportunities in tourism industry
}

\author{
Anang Sutono ${ }^{\mathbf{a}^{*}}$
}

${ }^{a}$ Sekolah Tinggi Pariwisata Bandung, Jawa Barat Indonesia

\begin{tabular}{l}
\hline C H R O N I C L E \\
\hline Article history: \\
Received October 7, 2018 \\
Accepted December 62018 \\
Available online \\
December 102018 \\
\hline Keywords: \\
Supply chain \\
Customer relationship \\
management \\
Tourism industry performance \\
Marketing planning capabilities \\
Marketing implementation \\
capabilities \\
Customer orientation \\
Knowledge management
\end{tabular}

\section{A B S T R A C T}

\begin{abstract}
With worldwide growth in tourism, most of the countries have begun to consider the importance of the tourism industry. However, the Indonesian tourism industry is not working with reasonable performance to contribute to economic development. This industry is lacking a good supply chain in hotel industry and the performance is not promising. Therefore, this study addressed this issue by considering supply chain marketing planning capabilities and supply chain marketing implementation capabilities to facilitate tourism industry with better supply chain management in Indonesian hotels for attracting tourists. Thus, the primary objective of this study is to examine the role of supply chain marketing planning capabilities and supply chain marketing implementation capabilities to boost tourism industry performance. The results indicate that supply chain management was the most crucial issue for attracting tourists. It was also found that supply chain marketing planning capabilities and better supply chain marketing implementation capabilities were the most important factors to enhance the tourism industry performance through customer orientation and knowledge management.
\end{abstract}

(C) 2019 by the authors; licensee Growing Science, Canada

\section{Introduction}

Tourism is the fastest growing sector in numerous countries. Internationally, as an export class, its ranking is fourth after fuel, food, and chemicals (UNWTO, 2012). Furthermore, it provides the opportunity to create jobs as well as inspires progress in most developing countries. According to the estimations, global tourism reached about US\$ 1,075 billion in the year 2012, from US\$1,042 billion in the year 2011 (UNWTO, 2013). Therefore, the worldwide tourism industry has been growing day by day having great economic importance for most developing countries (Oh, 2005; Roudi et al., 2018; Briandana et al., 2018), like Indonesia. The existing performance of the tourism industry can be increased with the help of better supply chain in the hotel industry since the hotel and the tourism industries have an important relationship with each other's (Holjevac, 2003; Mueller \& Kaufmann, 2001). Good supply chain activities in hotels have the potential to enhance the tourism industry. With this worldwide growth in tourism, nations have begun to consider the tourism industry on a priority basis. Tourism and the hotel industry have a positive effect in numerous countries' economy, giving foreign currency, supporting the balance of payment in a positive way and having a positive influence on debt repayments. The hotel industry is considered a central component of the tourism sector, and its

\footnotetext{
* Corresponding author

E-mail address: anang@stp-bandung.ac.id (A. Sutono) 
good performance assumes the vital job in upgrading economic growth (Zailani et al., 2011) with the help of tourism. It gives opportunities for creating jobs and contributes to reduce the unemployment rate. In spite of the fact that various hotels offer seasonal employments, many people are still interested in such job opportunities. The hotel industry additionally boosts different enterprises and has a multiplier impact. In this way, governments should give attention for the further advancement of the hotel industry and boost the tourism industry (Mohammad, 2014). As the tourism and hotel industry have a significant relationship with each other, it has a reasonable contribution to economic growth (Chen, 2010; Lee \& Chang, 2008; Pine et al., 2013; Okon, 2014; Khan \& Rasheed, 2016; Hussien \& Jones, 2016; Erdogan, 2016; Mayan \& Nor, 2017; Yu-Chi \& Lin, 2018; Taqi et al., 2018; Yu-Chi, 2018). Tourism and hotel industry also contribute in the gross domestic product (GDP) in most of the countries (Roe \& Urquhart, 2001; Schmidgall, 2002; Slobodan et al., 2015).

Fig. 1 shows the contribution of the top ten countries in terms of their national revenues through the tourism industry. It is evident that Australia has the highest contribution followed by Singapore. After Australia and Singapore, Malaysia maintains the highest contribution followed by the Chinese tourism industry. Increases in revenue contribution also increases economic growth. Better performance of the tourism industry has a positive influence on the GDP. This is also one of the reasons that Australia, Singapore, and China preserve higher GDP. These countries have better hotel supply chain activities which play an important role on the performance of tourism industry since better hotel supply chain management attracts more customers by fulfilling their needs (Kothari et al., 2005).

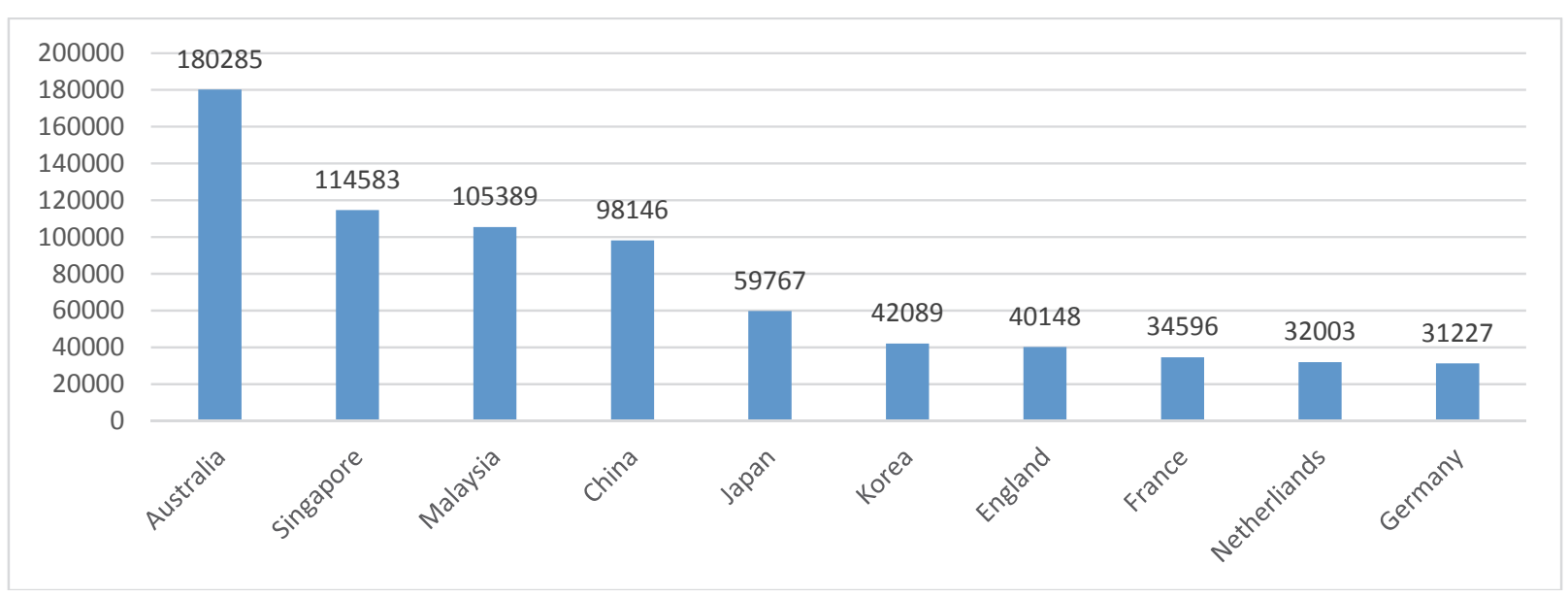

Fig. 1. Top ten countries with a high contribution to national revenue through tourism. Source: Passenger Exit Survey, Ministry of Tourism, Indonesia (2017)

However, the Indonesian tourism industry is not working with reasonable performance. This industry is lacking good supply chain activities in Indonesia. Low level of supply chain activities in Indonesian hotel industry influenced negatively on the tourism industry. That is the reason Fig. 1 shows that Indonesia is not in the list of top ten tourism industries. Even though the Indonesian nation maintains significant amount of potentials to attract tourists worldwide (Gunawan, 1999; Lindquist, 2009). Indonesian tourism industry performance can be increased with the help of better customer relationship management (CRM) activities and better supply chain capabilities in Indonesian hotels. CRM includes customer orientation and knowledge management. Better supply chain marketing planning capabilities and better supply chain implementation capabilities can enhance the tourism industry performance with the help of customer orientation and knowledge management. As demonstrated by Mohammad (2014), marketing planning capabilities and marketing implementation capabilities have positive effects on tourism performance. Fig. 2 shows how supply chain marketing planning capabilities and better supply chain marketing implementation capabilities enhance the performance of the tourism industry. Thus, the primary objective of this study is to examine the role of supply chain marketing planning 
capabilities and better supply chain marketing implementation capabilities to boost tourism industry performance. Other sub-objectives are

1. To examine the role of customer orientation in tourism industry performance,

2. To examine the role of knowledge management in tourism industry performance,

3. To examine the mediating role of supply chain marketing planning capabilities.

4. To examine the mediating role of supply chain marketing implementation capabilities.

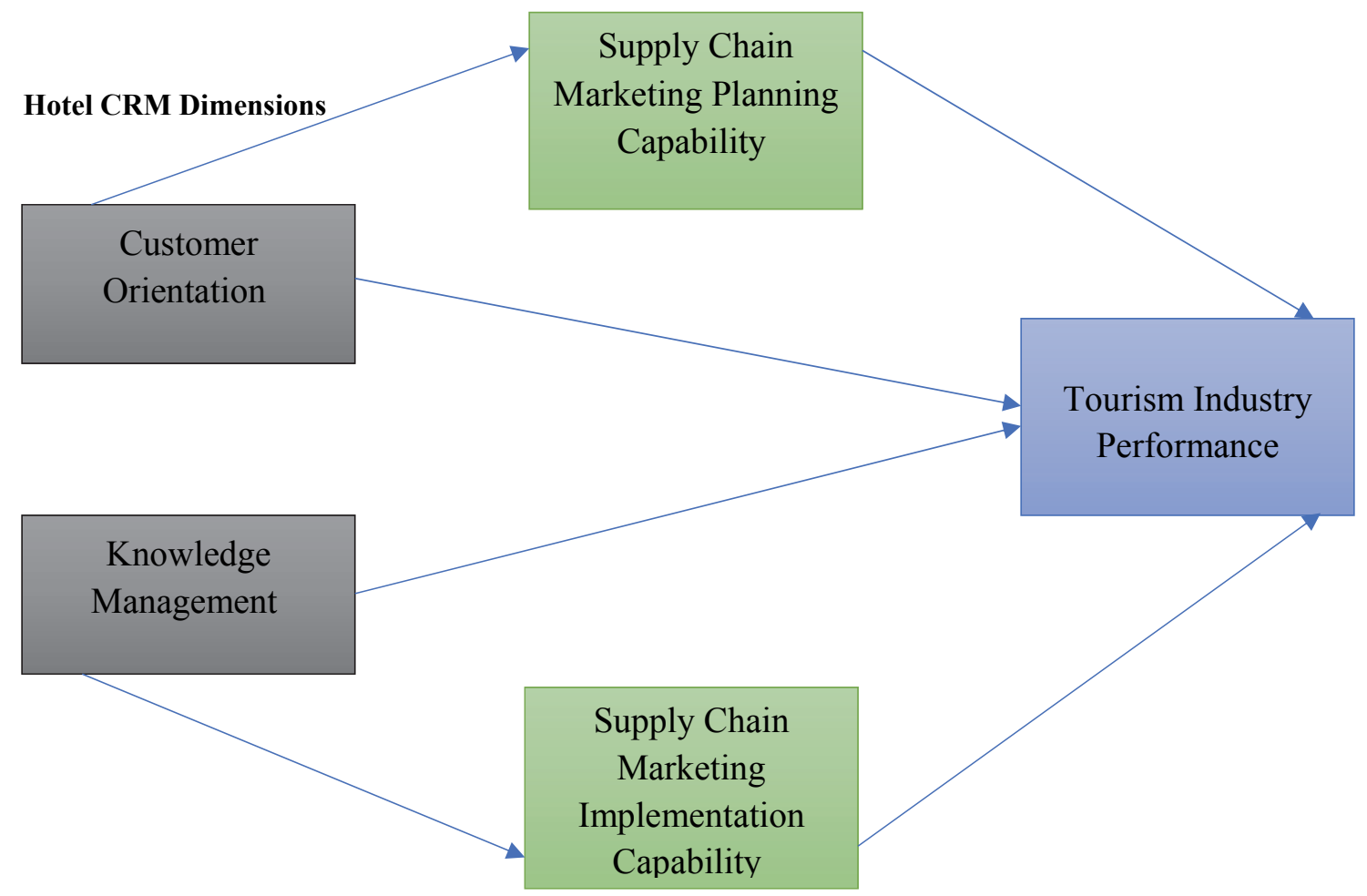

Fig. 2. The thoritical framework of the current study showing that how supply chain marketing planning capabilities and better supply chain marketing implementation capabilities enhance the performance of the

\section{Hypotheses Development} tourism industry

\subsection{Customer Orientation and Tourism Industry Performance}

Most investigations have utilized terms including customer orientation, marketing orientation, advertising idea and market-cantered associations in which customer needs are served as the point of intention for all the organization's design as well as techniques (Abdullateef, 2011; McEachern \& Warnaby, 2005; Yueh et al., 2010). Therefore, Indonesian hotels are needed to be consumer orientated to attract tourists. Customer orientation facilitates better hotel supply chain activities which ultimately enhances the hotel services.

Customer orientation always has a positive effect on business performance (Appiah-Adu \& Singh, 1998; Brockman et al., 2012; Sik Jeong \& Hong, 2007). Kotler (2004) called the requirement for a firm to move from the dimension of considering customer division to create separate administrations, items, and messages for individual customers and the organizations should gather adequate data with respect to customers, for example, past transactions, socioeconomics, and media. On this premise, advancement of high customer lifetime can possibly enable companies to accomplish productive growth. It increases the customer satisfaction level, however, with the customer satisfaction, the employee's job satisfaction is also important (Shah et al., 2018) to produce good services from the firm. Therefore, customer orientation is also import to enhance tourism industry performance. 
$\mathbf{H}_{1}$ : Customer orientation has a significant impact on tourism industry performance.

\subsection{Knowledge Management and Tourism Industry Performance}

Knowledge management capacities are characterized as the firm utilization of data reliably to manage, handle and transmit data with respect to customer and administrations with the goal to meet customer needs (Alavi \& Leidner, 2001). Knowledge management helps an organizational procedure and is associated with the creation, recovery, and utilization of knowledge about the customer to attain competitive advantage (Hamel \& Prahalad, 1990) and it is critical for every organization success.

In recent years, knowledge has grown to become a critical organizational resource, and the procedures for the transmission of knowledge in regard to customers because customers are the key resources that enable the organization to reinforce its connections with customers and accomplish competitive advantage (Croteau \& Li, 2003; Shi \& Yip, 2007). Better collaboration with customers, suppliers and external partners generates new ideas which creates innovation (Hameed et al., 2018). Knowledge from customers and other partners help to develop customized services which ultimately enhances and satisfies the tourists.

According to previous studies, knowledge management has a positive effect on business performance (Bueren et al., 2004; Gloet \& Terziovski, 2004; Zack et al., 2009). Therefore, to boost the tourism industry performance, the relationship between knowledge management and hotel services are important. Increases in knowledge management capabilities will ultimately increase tourism industry performance.

$\mathbf{H}_{2}$ : Knowledge Management has a significant impact on tourism industry performance.

\subsection{Supply Chain Marketing Planning Capabilities}

Supply chain marketing planning capabilities are always crucial to capture the customers. It can be defined as how a company organizes its supply chain capabilities to efficiently perform the marketing planning. Marketing planning is the procedure that utilizes explicit techniques to deal with the structure and usage of the company future (Pulendran \& Speed, 1996). In any case, Slotegraaf and Dickson (2004) characterized marketing planning capacity as the company's capacity to imagine and react to market changes with the point of guiding its resources and activities to fit the organization to nature and the extreme achievement of organizational financial related targets. Better planning capabilities help to capture the customers.

As the marketing capabilities always have a positive association with customers (Guenzi \& Troilo, 2006) it may increase the company's intention to develop customer focus strategies (Vorhies et al., 2011). Increases in customer focus strategies increase the value-added services. Thus, hotel supply chain activities related to marketing planning capabilities have a positive role in customer satisfaction. Moreover, marketing capabilities always have a strong relationship with performance (Mohammed \& Rashid, 2012; Morgan et al., 2009; Theodosiou et al., 2012). Therefore, in hotel supply chain performance, marketing planning capabilities are important to consider. Increases in marketing planning capabilities will definitely increase the customer orientation and tourism industry performance.

H3: Supply chain marketing planning capabilities have a significant impact on tourism industry performance.

$\mathbf{H}_{4}$ : Supply chain marketing planning capabilities mediates the relationship between customer orientation and tourism industry performance. 


\subsection{Supply Chain Marketing Implementation Capabilities}

Supply chain marketing implementation capabilities are important to enhance the performance of the tourism industry by enhancing the positive role of knowledge management on performance. Knowledge management is useless as long as it is not implemented with the help of various strategies. Hotel supply chain activities can be increased with the help of knowledge management through implementation capabilities. It can be defined as how a company organizes its supply chain capabilities to efficiently perform the marketing implementation strategies. In both cases, knowledge management and supply chain management and implementation capabilities are important. As both the knowledge management and organizational capabilities are normally correlated (Gold et al., 2001). As indicated by Kotler and Keller (2005), marketing implementation capability is the process that changes plan into activities, while Farjoun (2002) expressed that implementation is the carrying on the methodology. Along these lines, the implementation technique is considered as the process of making procedural work and deciding the components that are expected to change the plan energetically (Piercy, 2002). However, in this process, the supply chain has a critical role. Marketing implementation capabilities with hotel supply chain may influence the tourism industry. Thus, supply chain marketing implementation capability is one of the procedures whose result can be attained and explained by the firm specific skills to transform resources into marketing plans as well as actions that are attainable (Eisenhardt \& Martin, 2000) which leads to better performance. Therefore, supply chain marketing implementation capabilities enhance the customer's satisfaction in hotels which increases the tourism industry performance.

H5: Supply chain marketing implementation capabilities have a significant impact on tourism industry performance.

H6: Supply chain marketing implementation capabilities mediates the relationship between knowledge management and tourism industry performance

Additionally, it is evident from the literature that,

H7: Customer orientation has a significant impact on supply chain marketing planning capabilities.

$\mathbf{H}_{8}$ : Knowledge management has a significant impact on supply chain marketing implementation capabilities.

\section{Research Methodology}

Generally, three types of methodologies are used in social sciences; namely quantitative research techniques, qualitative research techniques and finally, mixed method research techniques. According to Denzin and Lincoln (2005) "qualitative research is a field of inquiry. It crosses cuts disciplines, fields, and subject matters". Moreover, they described that "qualitative research methodology is a situated activity that locates the observer in the world and consists of a set interpretive material, practices that make the world visible" (p. 3). On the other hand, quantitative research is a structured way of gathering as well as analysing data from various sources. It includes the utilization of computational, mathematical and statistical software packages to get results. Finally, the mix method approach is based on both quantitative research techniques and qualitative research techniques.

However, this study is carried out with the help of quantitative research techniques in which a survey was used to gather the data from managerial employees of various hotels in Indonesia. In the survey, all employees with direct relationship with hotel supply chain dealing with tourists on daily basis collected the necessary data. The managerial employees having no relationship with the hotel supply chain or tourists were not allowed to take part in the survey. In this study, a 5-point Likert scale was preferred. A 5-point scale was used because it is one of the most suitable scales to increase the reliability 
of data by reducing the respondent frustration level (Imran et al., 2018). The survey instrument was based on two parts and 500 questionnaires were distributed. One part consisted of respondent's profile and the second part was based on the major questions based on the key variables of this study. Additionally, this study followed PLS-SEM for data analysis as shown in Fig. 3.

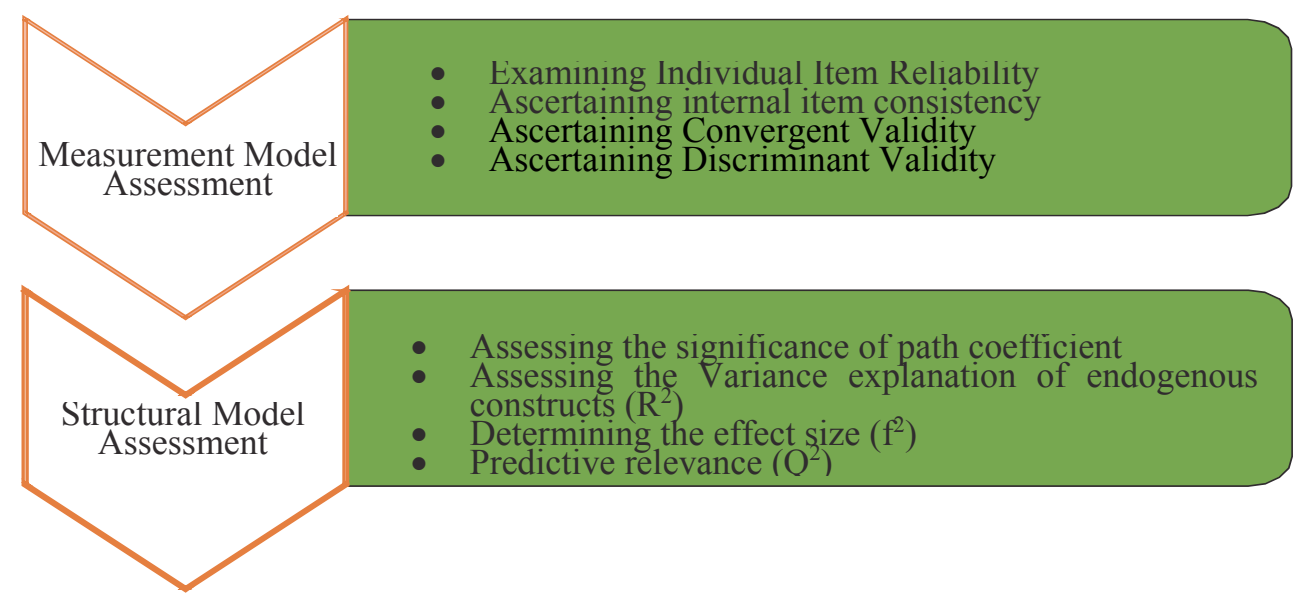

Fig. 3. PLS-SEM steps

Source: Hameed et al. (2018)

\section{Data Analysis and Findindgs}

The analysis of the study followed steps recommended by Henseler et al. (2009) as compiled by Hameed et al. (2018), shown in Fig. 3. These are the recommended steps while analysing the data through PLS-structural equation modeling techniques. This is most suitable techniques while analysing the data recommended by various other studies (Reinartz et al., 2009). All steps of PLS-SEM are given below in Fig. 4 and Fig. 5 and the results are given in related tables.

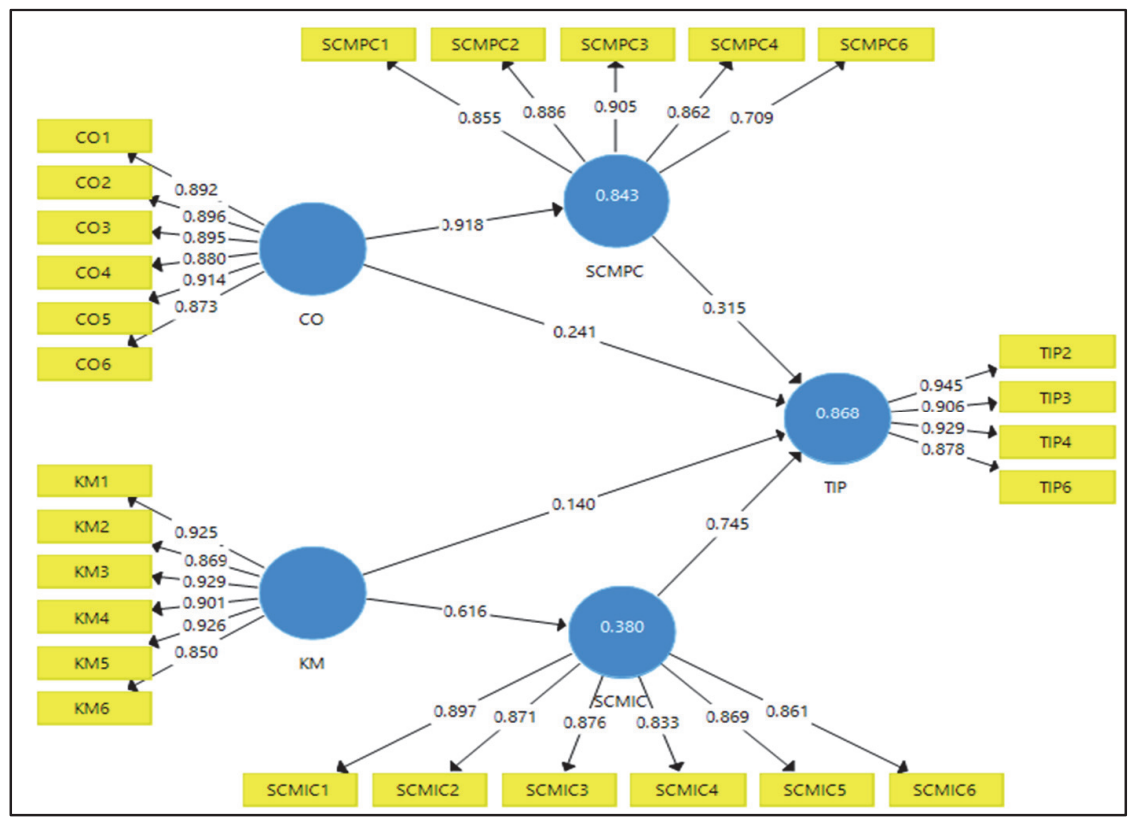

Fig. 4. Outer Model Assessment

Table 1 and Fig. 4 depict the factor loadings or outer loadings of the items. It is clear that all loadings are above 0.7 , a minimum threshold level in the current study which is recommended by Henseler et al. (2009) and it indicates internal consistency. Therefore, the current study achieved internal consistency. 
Table 1

Outer Loadings

\begin{tabular}{|c|c|c|c|c|c|}
\hline & $\mathrm{CO}$ & KM & SCMIC & SCMPC & TIP \\
\hline $\mathrm{CO} 1$ & 0.892 & & & & \\
\hline $\mathrm{CO} 2$ & 0.896 & & & & \\
\hline $\mathrm{CO} 3$ & 0.895 & & & & \\
\hline $\mathrm{CO} 4$ & 0.880 & & & & \\
\hline $\mathrm{CO} 5$ & 0.914 & & & & \\
\hline $\mathrm{CO} 6$ & 0.873 & & & & \\
\hline KM1 & & 0.925 & & & \\
\hline KM2 & & 0.869 & & & \\
\hline KM3 & & 0.929 & & & \\
\hline KM4 & & 0.901 & & & \\
\hline KM5 & & 0.926 & & & \\
\hline KM6 & & 0.850 & & & \\
\hline SCMIC1 & & & 0.897 & & \\
\hline SCMIC2 & & & 0.871 & & \\
\hline SCMIC3 & & & 0.876 & & \\
\hline SCMIC4 & & & 0.833 & & \\
\hline SCMIC5 & & & 0.869 & & \\
\hline SCMIC6 & & & 0.861 & & \\
\hline SCMPC1 & & & & 0.855 & \\
\hline SCMPC2 & & & & 0.886 & \\
\hline SCMPC3 & & & & 0.905 & \\
\hline SCMPC4 & & & & 0.862 & \\
\hline SCMPC6 & & & & 0.709 & \\
\hline TIP2 & & & & & 0.945 \\
\hline TIP3 & & & & & 0.906 \\
\hline TIP4 & & & & & 0.929 \\
\hline TIP6 & & & & & 0.878 \\
\hline
\end{tabular}

Moreover, reliability and convergent validity of the current study are portrayed in Table 2 . It is shown that alpha is above 0.7 , composite reliability (CR) is also above 0.7 and average variance extracted is also above 0.5 which show the external consistency in the data. Additionally, discriminant validity is given in Table 3.

\section{Table 2}

Reliability and Convergent Validity

\begin{tabular}{lllll}
\hline & $\alpha$ & rho A & CR & $($ AVE) \\
\hline CO & 0.948 & 0.949 & 0.959 & 0.795 \\
KM & 0.953 & 0.956 & 0.963 & 0.811 \\
SCMIC & 0.934 & 0.935 & 0.948 & 0.753 \\
SCMPC & 0.899 & 0.901 & 0.926 & 0.716 \\
TIP & 0.935 & 0.937 & 0.954 & 0.837 \\
\hline
\end{tabular}

Table 3

Discriminant validity

\begin{tabular}{llllll}
\hline & CO & KM & SCMIC & SCMPC & TIP \\
\hline CO & 0.892 & & & & \\
KM & 0.810 & 0.900 & & & \\
SCMIC & 0.631 & 0.616 & 0.868 & 0.846 & 0.915 \\
SCMPC & 0.818 & 0.808 & 0.754 & 0.783 & 0.817 \\
TIP & 0.644 & 0.668 & & \\
\hline
\end{tabular}

\subsection{Structural Model Assessment}

The structural model was carried out to test the hypotheses which were developed in section 2 of this study. It is a suitable technique to test the hypotheses as suggested by Henseler et al. (2009). In this technique bootstrapping with the help of PLS was carried out. Fig. 5 depicts the PLS bootstrapping. It 
shows the relationship between dependent variables (tourism industry performance), independent variables (customer orientation, knowledge management) and mediating variables (supply chain marketing planning capabilities and better supply chain marketing implementation capabilities).

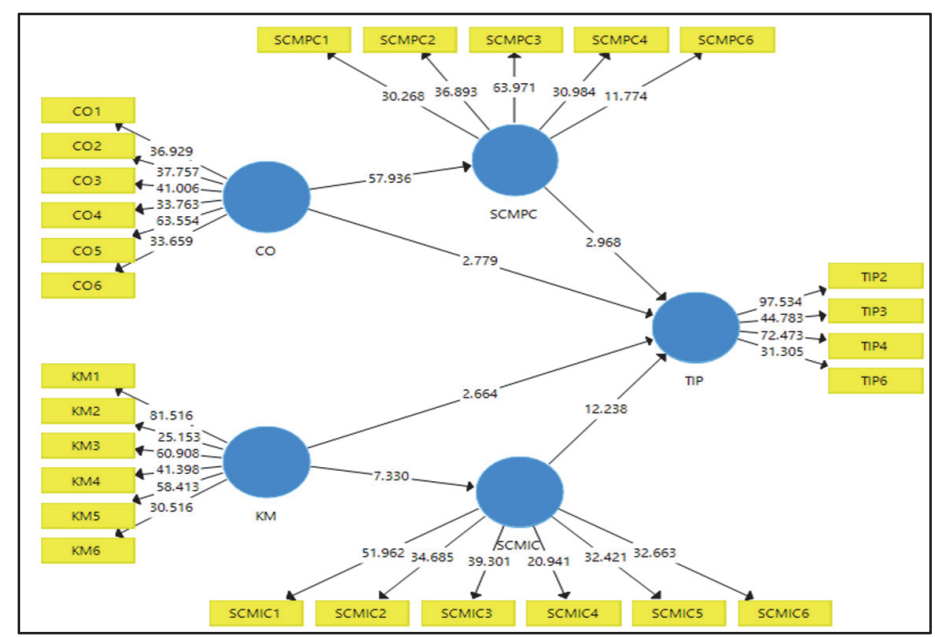

Table 4

Fig. 5. Structural Model Assessment

Direct Effect

\begin{tabular}{llllll}
\hline & $(\mathrm{O})$ & $(\mathrm{M})$ & $($ STDEV) & T Statistics & P Values \\
\hline $\mathrm{CO} \rightarrow$ SCMPC & 0.918 & 0.920 & 0.016 & 57.936 & 0.000 \\
$\mathrm{CO} \rightarrow$ TIP & 0.241 & 0.234 & 0.087 & 2.779 & 0.006 \\
$\mathrm{KM} \rightarrow$ SCMIC & 0.616 & 0.618 & 0.084 & 7.330 & 0.000 \\
$\mathrm{KM} \rightarrow$ TIP & 0.140 & 0.146 & 0.053 & 2.664 & 0.007 \\
$\mathrm{SCMIC} \rightarrow$ TIP & 0.745 & 0.741 & 0.061 & 12.238 & 0.000 \\
$\mathrm{SCMPC} \rightarrow$ TIP & 0.315 & 0.307 & 0.106 & 2.968 & 0.003 \\
\hline
\end{tabular}

The results of the structural model are given in Table 4. The t-value for all the relationship is also given in Fig. 5. All the relationship has t-value above 1.96, which is the minimum criteria to accept the hypotheses. It indicates that all the hypotheses have achieved a minimum level. Thus, all the direct hypotheses $\left(\mathrm{H}_{1}, \mathrm{H}_{2}, \mathrm{H}_{3}, \mathrm{H}_{4}, \mathrm{H}_{7}, \mathrm{H}_{8}\right)$ are accepted in this study. In case of mediation effect of supply chain marketing planning capabilities and supply chain marketing implementation capabilities, both hypotheses $\left(\mathrm{H}_{5}, \mathrm{H}_{6}\right)$ are accepted. Additionally, the R-Square value is 0.868 in this study which is substantial (Chin, 1998). Additionally, the histogram of the mediation effect for both mediators is shown in Fig. 6 and Fig. 7.

Table 5

In-Direct Effect

\begin{tabular}{llllll}
\hline & $(\mathrm{O})$ & $(\mathrm{M})$ & $($ STDEV) & T Statistics & P Values \\
$\mathrm{KM} \rightarrow$ SCMIC $\rightarrow$ TIP & 0.459 & 0.456 & 0.055 & 8.305 & 0.000 \\
$\mathrm{CO} \rightarrow \mathrm{SCMPC} \rightarrow$ TIP & 0.289 & 0.282 & 0.097 & 2.973 & 0.003 \\
\hline
\end{tabular}

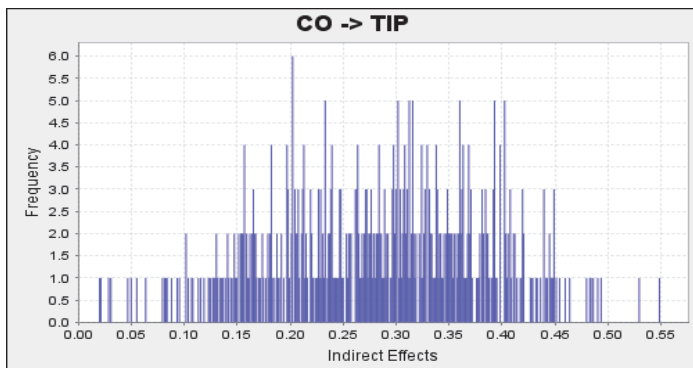

Fig. 6. Mediation effect of supply chain marketing planning capabilities between customer orientation and tourism industry performance

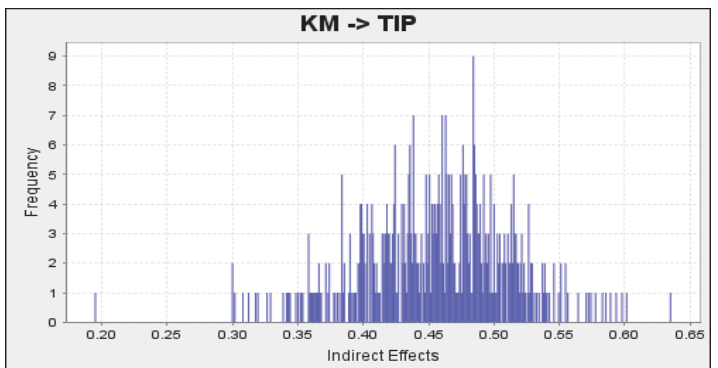

Fig. 7. Mediation effect of supply chain marketing implimentation capabilities between knowledge management and tourism industry performance 


\section{Discussion and Conclusion}

The current study has carried out to investigate the effects of SCM in hotel and tourism industry. The Indonesian tourism industry performance was not sufficient to contribute to economic development. It was found that Indonesian hotels are lacking in good supply chain activities. Therefore, this study is one of the attempts to apply better supply chain practices in hotels to enhance tourism industry performance. Data were collected from the managerial staff of hotels in Indonesia. In this purpose, supply chain marketing planning capabilities and supply chain marketing implementation capabilities were considered as the major elements to boost hotel supply chain and tourism industry performance. Additionally, two dimensions of CRM, namely; customer orientation and knowledge management were selected. While analysing the data, it was found that the supply chain in hotels played a major role to enhance tourism industry performance. Customer orientation and knowledge management have maintained a significant positive effect on tourism industry performance. Increase in the hotel intention towards customer orientation and knowledge management could increase the satisfaction among tourists which could also enhance the overall performance. Other studies also found similar results with the current study such as Tajeddini and Trueman (2008); Zhu and Nakata (2007) and Pekovic and Rolland (2016). Therefore, the results of the study are also consistent with prior literature.

Moreover, it was found that supply chain marketing planning capabilities and supply chain marketing implementation capabilities have played the most crucial role to enhance hotel supply chain and tourism industry performance. Supply chain marketing planning capabilities and supply chain marketing implementation capabilities enhanced the positive effect of customer orientation and knowledge management. Both planning capabilities and implementation capabilities have had positive effects on tourism industry performance. Therefore, Indonesian hotel management must insure good supply chain supply chain marketing planning capabilities and supply chain marketing implementation capabilities to enhance CRM and tourism industry performance. Finally, the supply chain has shown a vital contribution to the CRM and tourism industry performance.

\section{References}

Abdullateef, A. O. (2011). The Impact of Customer Relationship Management on Caller Satisfactions in Customer Contact Centers: Evidence from Malaysia. Universiti Utara Malaysia.

Alavi, M., \& Leidner, D. E. (2001). Knowledge management and knowledge management systems: Conceptual foundations and research issues. MIS quarterly, 25(1), 107-136.

Appiah-Adu, K., \& Singh, S. (1998). Customer orientation and performance: a study of SMEs. Management Decision, 36(6), 385-394.

Briandana, R., Doktoralina, C. M., \& Sukmajati, D. (2018). Promotion analysis of marine tourism in Indonesia: A case atudy. European Research Studies Journal, 21(1), 602-613

Brockman, B. K., Jones, M. A., \& Becherer, R. C. (2012). Customer orientation and performance in small firms: Examining the moderating influence of risk-taking, innovativeness, and opportunity focus. Journal of Small Business Management, 50(3), 429-446.

Bueren, A., Schierholz, R., Kolbe, L., \& Brenner, W. (2004). Customer knowledge managementimproving performance of customer relationship management with knowledge management. Paper presented at the System Sciences, 2004. Proceedings of the 37th Annual Hawaii International Conference on.

Chen, M.-H. (2010). The economy, tourism growth and corporate performance in the Taiwanese hotel industry. Tourism Management, 31(5), 665-675.

Chin, W. W. (1998). The partial least squares approach to structural equation modeling. Modern Methods for Business Research, 295(2), 295-336.

Croteau, A. M., \& Li, P. (2003). Critical success factors of CRM technological initiatives. Canadian Journal of Administrative Sciences/Revue Canadienne des Sciences de l'Administration, 20(1), 21 34. 
Denzin, N. K., \& Lincoln, Y. S. (2005). The Sage handbook of qualitative research. Sage Publications Ltd.

Eisenhardt, K. M., \& Martin, J. A. (2000). Dynamic capabilities: what are they? Strategic Management Journal, 21(10-11), 1105-1121.

Erdogan, A. I. (2016). Investigating the demand of small hotel and restaurant businesses for bank financing: The case of Turkey. Journal of Empirical Studies, 3(1), 1-6.

Farjoun, M. (2002). Towards an organic perspective on strategy. Strategic Management Journal, 23(7), 561-594.

Gloet, M., \& Terziovski, M. (2004). Exploring the relationship between knowledge management practices and innovation performance. Journal of Manufacturing Technology Management, 15(5), 402-409.

Gold, A. H., Malhotra, A., \& Segars, A. H. (2001). Knowledge management: An organizational capabilities perspective. Journal of Management Information Systems, 18(1), 185-214.

Guenzi, P., \& Troilo, G. (2006). Developing marketing capabilities for customer value creation through Marketing-Sales integration. Industrial Marketing Management, 35(8), 974-988.

Gunawan, M. (1999). Indonesian tourism: development policies and the challenge for research and education. Pookong, K. and King, B. Asia-Pacific Tourism; Regional Cooperation, Planning and Development.: Hospitality Press, Victoria, 147-164.

Hameed, W. U., Basheer, M. F., Iqbal, J., Anwar, A., \& Ahmad, H. K. (2018). Determinants of Firm's open innovation performance and the role of $\mathrm{R} \& \mathrm{D}$ department: an empirical evidence from Malaysian SME's. Journal of Global Entrepreneurship Research, 8(1), 29.

Hamel, G., \& Prahalad, C. (1990). Strategic intent. Harvard Business Review, 67(3), 63-76.

Henseler, J., Ringle, C. M., \& Sinkovics, R. R. (2009). The use of partial least squares path modeling in international marketing New challenges to international marketing (pp. 277-319): Emerald Group Publishing Limited.

Holjevac, I. A. (2003). A vision of tourism and the hotel industry in the 21 st century. International Journal of Hospitality Management, 22(2), 129-134.

Hussien, F. M., \& Jones, E. (2016). The requirements of disabled customers: a study of British customers in Egyptian hotels. Journal of Tourism Management Research, 3(2), 56-73.

Imran, M., Hameed, W., U1, \& Haque, A., UL, . (2018). Influence of industry 4.0 on the production and service sectors in Pakistan: Evidence from textile and logistics industries. Social Sciences, 7(12), 246.

Khan, R. E. A., \& Rasheed, M. K. (2016). Political economy of tourism in Pakistan: The role of terrorism and infrastructure development. Asian Development Policy Review, 4(2), 42-50.

Kothari, T., Hu, C., \& Roehl, W. S. (2005). e-Procurement: an emerging tool for the hotel supply chain management. International Journal of Hospitality Management, 24(3), 369-389.

Kotler, P., \& KELLER, L. (2005). Kevin. Marketing management, 348.

Lee, C.-C., \& Chang, C.-P. (2008). Tourism development and economic growth: A closer look at panels. Tourism Management, 29(1), 180-192.

Lindquist, J. A. (2009). The anxieties of mobility: Migration and tourism in the Indonesian borderlands. University of Hawaii Press.

Mayan, S. N. A., \& Nor, R. M. (2017). Prospects and challenges of ecotourism sector and poverty eradication in Sabah: The case of orangutans and Mabul Island. Global Journal of Social Sciences Studies, 3(1), 1-12.

McEachern, M., \& Warnaby, G. G. (2005). Improving customer orientation within the fresh meat supply chain: A focus on assurance schemes. Journal of Marketing Management, 21(1-2), 89-115.

Mohammad, A. A. M. (2014). The mediating effect of marketing capabilities on the relationship between customer relationship management (CRM) dimensions and hotel performance. Universiti Utara Malaysia.

Mohammed, A. A., \& Rashid, B. (2012). Customer Relationship Management (CRM) in hotel industry: A framework proposal on the relationship among CRM dimensions, marketing capabilities, and hotel performance. International Review of Management and Marketing, 2(4), 220-230. 
Morgan, N. A., Vorhies, D. W., \& Mason, C. H. (2009). Market orientation, marketing capabilities, and firm performance. Strategic Management Journal, 30(8), 909-920.

Mueller, H., \& Kaufmann, E. L. (2001). Wellness tourism: Market analysis of a special health tourism segment and implications for the hotel industry. Journal of Vacation Marketing, 7(1), 5-17.

Oh, C.-O. (2005). The contribution of tourism development to economic growth in the Korean economy. Tourism Management, 26(1), 39-44.

Okon, E. O. (2014). Inbound tourism and social factors in Nigeria: Evidence from an Ardl-Ecm Model. Asian Journal of Economics and Empirical Research, 1(2), 40-47.

Pekovic, S., \& Rolland, S. (2016). Customer orientation and firm's business performance: A moderated mediation model of environmental customer innovation and contextual factors. European Journal of Marketing, 50(12), 2162-2191.

Piercy, N. F. (2002). Market-led Strategic Change: A Guide to Transforming the Process of Going to Market. 3rd edn Oxford: Butterworth-Heinemann.

Pine, R. J., Lam, T., \& Zhang, H. Q. (2013). Tourism and hotel development in China: From political to economic success. Routledge.

Pulendran, S., \& Speed, R. (1996). Planning and doing: the relationship between marketing planning styles and market orientation. Journal of Marketing Management, 12(1-3), 53-68.

Reinartz, W., Haenlein, M., \& Henseler, J. (2009). An empirical comparison of the efficacy of covariance-based and variance-based SEM. International Journal of research in Marketing, 26(4), 332-344.

Roe, D., \& Urquhart, P. (2001). Pro-poor tourism: harnessing the world's largest industry for the world's poor: IIED London.

Roudi, S., Arasli, H., \& Akadiri, S. S. (2018). New insights into an old issue-examining the influence of tourism on economic growth: evidence from selected small island developing states. Current Issues in Tourism, 1-21.

Schmidgall, R. S. (2002). Hospitality industry managerial accounting: Educational Institute of the American Hotel \& Lodging Association.

Shah, S. M. M., Ali, R., Dahri, A. S., Ahmed, N., \& Brohi, Z. A. M. (2018). Determinants of job satisfaction among Nurses: Evidence from South Asian Perspective. Journal of Academic Research in Business and Social Sciences, 8(5), 19-26.

Shi, J., \& Yip, L. (2007). Driving innovation and improving employee capability: The effects of customer knowledge sharing on CRM.

Sik Jeong, J., \& Hong, P. (2007). Customer orientation and performance outcomes in supply chain management. Journal of Enterprise Information Management, 20(5), 578-594.

Slobodan, Č., Vladimir, M., \& Ivana, B. (2015). The contribution of tourism industry on the GDP growth of Western Balkan countries. Industrija, 43(3), 159-170.

Slotegraaf, R. J., \& Dickson, P. R. (2004). The paradox of a marketing planning capability. Journal of the Academy of Marketing Science, 32(4), 371-385.

Tajeddini, K., \& Trueman, M. (2008). Effect of customer orientation and innovativeness on business performance: a study of small-sized service retailers. International Journal of Entrepreneurship and Small Business, 6(2), 280-295.

Taqi, M., Ajmal, M \& Ansari, M.S (2018). Financial efficiency of India tourism development corporation (ITDC) limited: An empirical study. Journal of Tourism Management Research, 5(1): 14-22.

Theodosiou, M., Kehagias, J., \& Katsikea, E. (2012). Strategic orientations, marketing capabilities and firm performance: An empirical investigation in the context of frontline managers in service organizations. Industrial Marketing Management, 41(7), 1058-1070.

UNWTO. (2012). Tourism Highlight 201 2, World Tourism Organization. Retrieved April 29 ,201 3 from http://dtxtq4w60xqpw.cloudfront.net/sites/alI/fi1es/docpdf/unwtohi hIights12enhr I.pdf.

UNWTO. (2013). Tourism Highlight 20 13, World Tourism Organization. Retrieved August 1 ,20 13 from http://n kt.unwto.org/en/publication/unwto-tourismhighlights-20 13-edition. 
Vorhies, D. W., Orr, L. M., \& Bush, V. D. (2011). Improving customer-focused marketing capabilities and firm financial performance via marketing exploration and exploitation. Journal of the Academy of Marketing Science, 39(5), 736-756.

Yu-Chi, S. (2018). Revisiting the tourism-led growth hypothesis in a dual model using Mwald Granger causality analysis. Asian Economic and Financial Review, 8(8), 1102-1110.

Yu-Chi, S., \& Lin, H. P. (2018). Causality relationship between tourism, foreign direct investment and economic growth in Taiwan. Asian Journal of Economic Modelling, 6(3), 287-293.

Yueh, C., Lee, Y., \& Barnes, F. B. (2010). The effects of leadership styles on knowledge-based customer relationship management implementation. International Journal of Management and Marketing Research, 3(1), 1-19.

Zack, M., McKeen, J., \& Singh, S. (2009). Knowledge management and organizational performance: an exploratory analysis. Journal of Knowledge Management, 13(6), 392-409.

Zailani, S., Omar, A., \& Kopong, S. (2011). An exploratory study on the factors influencing the noncompliance to halal among hoteliers in Malaysia. International Business Management, 5(1), 1-12.

Zhu, Z., \& Nakata, C. (2007). Reexamining the link between customer orientation and business performance: The role of information systems. Journal of Marketing Theory and Practice, 15(3), 187-203.

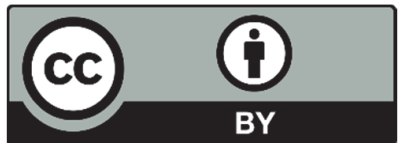

(C) 2019 by the authors; licensee Growing Science, Canada. This is an open access article distributed under the terms and conditions of the Creative Commons Attribution (CC-BY) license (http://creativecommons.org/licenses/by/4.0/). 